\title{
An evaluation of the characteristics of orthopedic pediatric traumas during the COVID-19 pandemic lockdown period
}

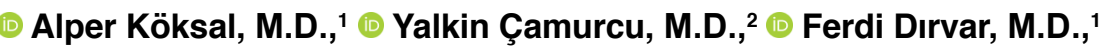 \\ Furkan Yapıcı, M.D., ${ }^{3}$ ㄴ) Hakan Akgün, M.D., ${ }^{1}$ 이 Ozan Kaya, M.D. ${ }^{1}$
}

\author{
${ }^{1}$ Department of Orthopaedics and Traumatology, University of Health Sciences, Baltalimanı Bone Diseases Training and \\ Research Hospital, İstanbul-Turkey \\ ${ }^{2}$ Department of Orthopaedics and Traumatology, İstanbul Atlas University Faculty of Medicine, İstanbul-Turkey \\ ${ }^{3}$ Department of Orthopaedics and Traumatology, Erzincan Binali Yıldırım University Faculty of Medicine, Erzincan-Turkey
}

\begin{abstract}
BACKGROUND: The purpose of this study is to investigate the effects of implemented social isolation measures on the characteristics of orthopedic pediatric traumas during this COVID-19 pandemic lockdown period.

METHODS: Patients who were admitted at our center between two time periods: April 3, 2019-May 31, 2019 (no lockdown period) and April 3, 2020-May 3I, 2020 (lockdown period) were included to the study. Group I comprised 743 patients who were treated during no lockdown period, whereas Group 2 comprised 615 patients who were treated during lockdown period. Patients' medical records and radiographs were reviewed through our hospital's computer database. In addition, we recorded each patients' age and gender, their definite diagnosis, the anatomic location of the trauma, the type of trauma (fracture, dislocation, tendon injury, ligament injury, fracture dislocation, open fracture, etc.), the type of pediatric fracture (displaced fracture, torus fracture, epiphyseal fracture, pathological fracture, etc.), and the treatment method (non-operative/operative).
\end{abstract}

RESULTS: The mean age of the patients was significantly lower in Group $2(p<0.00 \mathrm{I})$. There were significant differences between the groups in terms of anatomic locations of the traumas $(p<0.00 I)$. The types of the traumas, pediatric traumas, and treatment were significantly different between the groups $(p<0.001, p<0.001$, and $p<0.001$, respectively). The frequency of operative treatment was significantly higher in Group 2 ( $\mathrm{p}<0.00 \mathrm{I})$.

CONCLUSION: Our results demonstrated significant differences in patients' demographics as well as trauma characteristics during COVID-19 pandemic.

Keywords: Demographics; lockdown; pandemic; pediatric fractures; trauma.

\section{INTRODUCTION}

Growing pediatric long bones possess unique characteristics which foster distinctive fracture patterns and biomechanics. Compared to adult bones, pediatric bones have a more porous body and thicker periosteum which resist bending forces; hence, this situation results in special pediatric fracture types. Despite public health strategies such as public service announcements and advertisements for injury prevention, there has been an increase in the overall rate of fractures among children. ${ }^{[1-3]}$ Approximately half of all children will fracture at least one bone during childhood. ${ }^{[4]}$ Although falls from heights and injuries from contact sports continue to be the leading causes of fractures, the etiologies of pediatric fractures have evolved to include many new recreational and sporting activities. ${ }^{[5]}$

During their first II years, children of both genders are at an increased risk of fracture due to sustained accident or trauma. In fact, in this cohort, young males are at greater risk

Cite this article as: Köksal A, Çamurcu Y, Dırvar F, Yapıcı F, Akgün H, Kaya O. An evaluation of the characteristics of orthopedic pediatric traumas during the COVID-19 pandemic lockdown period. Ulus Travma Acil Cerrahi Derg 2022;28:94-98.

Address for correspondence: Alper Köksal, M.D.

SBÜ Baltalimanı Kemik Hastalıkları Eğitim ve Araştırma Hastanesi, Ortopedi ve Travmatoloji Bölümü, İstanbul, Turkey

Tel: +90 212 - 3237074 E-mail: dralperkoksal@gmail.com

Ulus Travma Acil Cerrahi Derg 2022;28(I):94-98 DOI: 10.14744/tjtes.2020.6768I Submitted: 04.08.2020 Accepted: 05.10.2020

Copyright 2022 Turkish Association of Trauma and Emergency Surgery 
than females. After the age of 13 or 14, the risk is twice as high for both boys and girls. ${ }^{[2]}$ Distal radius fractures are the most common type in the pediatric population. ${ }^{[2,6,7]}$ This is followed by fractures involving the phalanges of the hand. ${ }^{[2]}$ Supracondylar humerus fractures are the most common surgically treated fractures of the pediatric elbow. ${ }^{\left[{ }^{[1}\right.}$

In December 2019, a new type of coronavirus infection became prevalent in Wuhan, China. Since then, it has spread quickly across several regions of China and the globe. ${ }^{[9]}$ To date, the epidemic caused by this virus has affected the larger global population. The World Health Organization (WHO) named the disease coronavirus disease-2019 (COVID-19). After some evaluation, on March 12, 2020, the WHO announced that COVID- 19 had reached pandemic status. ${ }^{[10]}$ To minimize the risk of COVID- 19 transmission, varying regimes of countermeasures have been implemented by different countries. ${ }^{[1,12]}$

From April 3 until the end of May 2020, lockdown measures implemented in Turkey affected children under the age of 18. During this period, the authorities divided children into two groupings (<14 and >14 years old). Each cohort had a separate $4 \mathrm{~h}$ weekly allotment, between the hours of II AM and 3 PM, during which they were permitted outside on Wednesdays and Fridays, respectively. Our null hypothesis was that social isolation due to lockdown as well as restrictions on outdoor activities did not affect the incidence, location, and severity of orthopedic pediatric traumas. Accordingly, the purpose of this study is to investigate the effects of implemented social isolation measures on the characteristics of orthopedic pediatric traumas during this COVID-19 pandemic lockdown period.

\section{MATERIALS AND METHODS}

\section{Study Population}

This retrospective comparative study was performed after obtaining the approval of an Ethical Review Board. Informed consent was obtained for each patient. We retrospectively analyzed the data of patients aged from 0 to 18 years who were admitted to our Level III trauma center in Istanbul - one of the world's largest metropolitan cities, with a population of over 15 million persons.

Patients who were admitted to our center between the periods April 3, 2019, and May 31, 2019 (no lockdown in effect), and April 3, 2020-May 31, 2020 (lockdown in effect) were included in the study. Motor vehicle accidents and multitrauma cases were excluded from the study. A total of 1358 patients with a mean age of $8.1 \pm 5.0$ years (562 girls and 796 boys) were included in the study.

\section{Data Evaluation}

Patients' medical records and radiographs were reviewed through our hospital's computer database. In addition, we recorded each patients' age and gender, their definite diagnosis, the anatomic location of the trauma, the type of trauma (fracture, dislocation, tendon injury, ligament injury, fracture dislocation, open fracture, etc.), the type of pediatric fracture (displaced fracture, torus fracture, epiphyseal fracture, pathological fracture, etc.), and the treatment method (non-operative/operative). Patients were categorized according to the presence or absence of lockdown conditions. Group I consisted of 743 patients who were treated between April 3, 2019, and May 31, 2019 (no lockdown), whereas Group 2 comprised 615 patients who were treated between April 3, 2020, and May 31, 2020 (lockdown in effect).

\section{Statistical Analysis}

Statistical analysis was performed using SPSS 25.0 (SPSS Inc., IBM, NY, USA). Continuous variables were presented as means and standard deviations, whereas categorical variables were presented as frequencies and percentages. Means were compared using the Student's t-test and frequencies were compared using the Chi-square test. We also conducted Bonferroni analysis to carry out post hoc comparison between the groups. P-values lower than 0.05 were considered statistically significant for this study.

\section{RESULTS}

Table I presents the details of patients' demographics and the anatomic locations of the traumas. The mean age of the patients was significantly lower in Group $2(p<0.00$ I). There were notable differences between the groups in terms of the anatomic locations of the traumas $(p<0.001)$. The frequency of clavicle, humerus, hip (femoral neck and pertrochanteric), and femur fractures did not differ significantly between the groups ( $p>0.05)$. However, there were significant differences observed regarding other anatomic locations $(p<0.05)$.

Table 2 presents the characteristics of the patient traumas. The types of traumas, pediatric traumas, and treatments differed significantly between the groups $(p<0.001, p<0.001$, and $p<0.001$, respectively). There was no significant difference in terms of the distribution of open fractures, fracture dislocations, and tendon injuries between the groups $(p>0.05)$. The distribution of fractures and dislocations was also similar between the groups $(p>0.05)$. However, there was a significant decrease in ligament injuries as compared to fractures and dislocations during the lockdown period $(p<0.05)$.

The distribution of epiphyseal fractures and pathological fractures did not differ significantly between the groups. Nevertheless, the frequency of torus fractures decreased significantly as compared to displaced fractures during the lockdown period. Furthermore, the frequency of operative treatments was significantly higher in Group $2(p<0.00 \mathrm{I})$. 
Table I. Comparison of the demographics and anatomic locations of the pediatric trauma

\begin{tabular}{|c|c|c|c|}
\hline & Group I $(n=743)$ & Group $2(n=615)$ & p-values \\
\hline Age, mean $\pm S D$ & $8.9 \pm 4.9$ & $7.3 \pm 5.1$ & $<.001$ \\
\hline Gender, n (\%) & & & .470 \\
\hline Girl & $314(42)$ & $248(40)$ & \\
\hline Boy & $429(58)$ & $367(60)$ & \\
\hline Anatomic location, $\mathrm{n}(\%)^{*}$ & & & $<.001$ \\
\hline Clavicle & $23(3)^{a, b, c, d, e, f}$ & $22(4)^{a, b, c, d, e, f}$ & \\
\hline Humerus & $13(2)^{a, b, c, d, e, f}$ & $6(I)^{a, b, c, d, d, f, f}$ & \\
\hline Elbow & $179(24)^{a, c}$ & $240(39)^{a, c}$ & \\
\hline Forearm & $8 \mathrm{I}(\mathrm{II})^{\mathrm{b}, \mathrm{e}, \mathrm{f}}$ & $44(7)^{\mathrm{b}, \mathrm{e}, \mathrm{f}}$ & \\
\hline Wrist & $169(23)^{f}$ & $78(13)^{f}$ & \\
\hline Hand & $136(18)^{f}$ & $66(10.7)^{f}$ & \\
\hline Hip & $2(0.2)^{a, b, c, c, d, e, f}$ & $2(0.3)^{a, b, c, c, d, e, f}$ & \\
\hline Femur & $14(2)^{a, b, c, d, e, f f}$ & $19(3)^{\mathrm{a}, \mathrm{b}, \mathrm{c}, \mathrm{d}, \mathrm{e}, \mathrm{f}}$ & \\
\hline Patella & $6(0.8)^{a, b, d, d, f, f}$ & $0(0)^{a, b, d, e, f}$ & \\
\hline Tibia & $22(3)^{c}$ & $55(9)^{c}$ & \\
\hline Ankle & $53(7)^{\mathrm{d}, \mathrm{e}, \mathrm{f}}$ & $25(4)^{d, e, f}$ & \\
\hline Foot & $45(6)^{a, b, c, c, d, e}$ & $58(9)^{a, b, c, d, d, e}$ & \\
\hline
\end{tabular}

"Each subscript letter denotes a subset of "Anatomic Location" categories whose row proportions do not differ significantly from each other at the .05 level. SD: Standard deviation.

Table 2. Comparison of the characteristics of the pediatric traumas

\begin{tabular}{|c|c|c|c|}
\hline & Group I $(n=743)$ & Group $2(n=615)$ & p-values \\
\hline Type of trauma, n (\%) & & & $<.001$ \\
\hline Closed fracture & $584(79)^{\mathrm{a}}$ & $50 \mathrm{I}(8 \mathrm{I})^{\mathrm{a}}$ & \\
\hline Open fracture & $2(0.2)^{a, b}$ & $0(0)^{a, b}$ & \\
\hline Dislocation & $119(16)^{a}$ & $108(18)^{\mathrm{a}}$ & \\
\hline Fracture - dislocation & $10(1)^{a, b}$ & $3(0.5)^{\mathrm{a}, \mathrm{b}}$ & \\
\hline Tendon injury & $6(0.8)^{a, b}$ & $2(0.3)^{\mathrm{a}, \mathrm{b}}$ & \\
\hline Ligament injury & $22(3)^{\mathrm{b}}$ & $\mathrm{I}(0.2)^{\mathrm{b}}$ & \\
\hline Type of pediatric fracture, $n(\%)^{*}$ & & & $<.001$ \\
\hline Displaced fracture & $435(73)^{a}$ & $423(84)^{a}$ & \\
\hline Torus fracture & $127(21.3)^{\mathrm{b}}$ & $57(\mathrm{II})^{\mathrm{b}}$ & \\
\hline Epiphyseal fracture & $33(5.5)^{\mathrm{a}, \mathrm{b}}$ & $24(5)^{a, b}$ & \\
\hline Pathological fracture & I $(0.2)^{a, b}$ & $0(0)^{a, b}$ & \\
\hline Type of treatment, $\mathrm{n}(\%)$ & & & $<.001$ \\
\hline Non-operative & $693(93)$ & $521(85)$ & \\
\hline Operative & $50(7)$ & $94(15)$ & \\
\hline
\end{tabular}

"Each subscript letter denotes a subset of "Type of Trauma" and "Type of Pediatric Fracture" categories whose row proportions do not differ significantly from each other at the .05 level.

\section{DISCUSSION}

The most important finding of our study was the observation of significant differences in patient demographics and ortho- pedic trauma characteristics during the COVID-19 pandemic lockdown period. Therefore, our null hypothesis that social isolation due to lockdown as well as restrictions on outdoor 
activities did not affect the incidence, location, and severity of orthopedic pediatric traumas cannot be accepted.

The occurrence of fractures in children differs depending on many demographic factors such as season, climate, activity level, nutritional status, socioeconomic environment, gender, and age. ${ }^{[2,6,13]}$ It is difficult to compare all of these factors. Nevertheless, the comparison of a cohort over the same period and in the same city may obviate most environmental factors. Demographic comparison of the study groups demonstrated that the gender profile was similar in both. However, the mean age of the patients was significantly lower during the COVID-19 pandemic lockdown period in our study. Bram et al. ${ }^{[14]}$ also found similar results in their study during the COVID-19 pandemic period. The reason for the lower mean age may be due to isolation measures taken during the COVID-19 pandemic period; as adolescents could not perform typical athletic activities as frequently given that they spent the overwhelming majority of the week in the restricted confines of their homes.

There are limited data in the literature about the frequency of operative treatments for pediatric fractures during the pandemic period. Bram et al. ${ }^{[14]}$ suggested that there was a decrease in the number of fractures requiring surgery during this time. On the contrary, according to our findings, the frequency of operative treatment was significantly higher during the pandemic period. In this study, supracondylar humerus fractures were found to be the most common surgically treated fractures of the pediatric elbow, which is consistent with the findings of the available literature. ${ }^{[8]}$ Our results demonstrated that elbow fractures increased significantly, while fractures involving the forearm, wrist, and hand decreased significantly. Elbow fractures in children were most often treated operatively, while forearm, wrist, and hand fractures were mostly treated non-operatively. Hence, the increase in the number of surgical treatments may be explained by differences in the anatomical location of the trauma in question.

Normally, the most common fracture reported in children is a fracture of the distal radius, which accounts for $25-43 \%$ of all fractures followed by fractures of the fingers and carpal bones. ${ }^{[2,6,7,15-19]}$ In this study, the most common fractures were elbow fractures, followed by fractures of the wrist and of the hand, during both periods. Overall, fractures of the upper limb account for two-thirds of all childhood fractures, with lower limb fractures accounting for approximately onethird. ${ }^{[20-22]}$ The frequency of clavicle, humerus, hip (femoral neck and pertrochanteric), and femur fractures was the same among both groups in our study. The frequency of tibia and foot fractures was significantly increased during the pandemic period, whereas the frequency of forearm, wrist, hand, and ankle fractures was appreciably decreased. Due to the limited patient population, it is difficult to draw firm conclusions according to our results. However, the dramatic decrease in observed wrist and hand fractures may be explained by parents' general reluctance to visit hospitals and health-care facilities during the pandemic.

Our study reported a significant reduction in the frequency of torus fractures and ligament injuries. Bram et al. ${ }^{[14]}$ found similar results in their study. As these injuries are not so painful, parents were prohibited from bringing their children to the hospital due to the aforementioned fear of viral infection. These patients would have been expected to recover using traditional methods at home; as results have shown that non-rigid immobilizations can demonstrate better clinical efficacy than a rigid cast in terms of functional recovery, treatment costs, and complication rates. ${ }^{[23]}$

This study has some potential limitations which require careful consideration. First, the constraints inherent to a retrospective design may compromise the accuracy of data collection. Second, our center worked as a non-COVID orthopedic trauma center. This may have affected our results since we do not know the exact number of patients referred by other pandemic centers to our facility. The main strength, however, of our study is that it is the first in the literature that has evaluated the characteristics of orthopedic pediatric traumas during the COVID-19 lockdown period in comparison to one with no lockdown.

\section{Conclusion}

According to the results acquired through this study, we see significant differences in terms of the characteristics of the relevant traumas observed during the pandemic period compared to those seen last year. Elbow fractures were again the most common pediatric trauma in both periods. However, the ages of the trauma patients decreased significantly. Likewise, the frequency of elbow fractures increased notably, while that of forearm, elbow, and hand traumas decreased. In addition, the frequency of operative treatment was significantly higher at our trauma center during the pandemic period. Finally, the increased number of pediatric patients who required surgical management of injuries such as elbow traumas may have been affected by parents' avoidance of admitting hospitals for wrist and hand traumas which could be resolved through traditional immobilization methods.

Ethics Committee Approval: This study was approved by the Health Sciences University Metin Sabancı Baltalimanı Bone Diseases Training and Research Hospital Ethics Committee (Date: 09.06.2020, Decision No: 418).

Peer-review: Internally peer-reviewed.

Authorship Contributions: Concept: A.K.; Design: A.K.; Supervision: A.K.; Materials: A.K., H.A., O.K.; Data: A.K., H.A., O.K.; Analysis: A.K., F.D., F.Y.; Literature search: A.K., F.D., F.Y.; Writing: A.K., Y.Ç.; Critical revision: A.K. Y.Ç.

Conflict of Interest: None declared.

Financial Disclosure: The authors declared that this study has received no financial support. 


\section{REFERENCES}

1. Khosla S, Melton LJ 3rd, Dekutoski MB, Achenbach SJ, Oberg AL, Riggs BL. Incidence of childhood distal forearm fractures over 30 years: A population-based study. JAMA 2003;290:1479-85. [CrossRef]

2. Landin LA. Fracture patterns in children. Acta Orthop Scand 1983;54:634-40. [CrossRef]

3. Jonsson B, Bengner U, Redlund-Johnell I, Johnell O. Forearm fractures in Malmo, Sweden. Changes in the incidence occurring during the 1950s, 1980s and 1990s. Acta Orthop Scand 1999;70:129-32. [CrossRef]

4. Jones IE, Williams SM, Dow N, Goulding A. How many children remain fracture-free during growth? A longitudinal study of children and adolescents participating in the Dunedin multidisciplinary health and development study. Osteoporos Int 2002;13:990-5. [CrossRef]

5. Mathison DJ, Agrawal D An update on the epidemiology of pediatric fractures. Pediatr Emerg Care 2010;26:594-603. [CrossRef]

6. Cooper C, Dennison EM, Leufkens HG, Bishop N, van Staa TP. Epidemiology of childhood fractures in Britain: A study using the general practice research database. J Bone Miner Res 2004;19:1976-81. [CrossRef]

7. Bailey DA, Wedge JH, McCulloch RG, Martin AD, Bernhardson SC. Epidemiology of fractures of the distal end of the Radius in children as associated with growth. J Bone Joint Surg Am 1989;71:1225-31. [CrossRef]

8. Landin LA, Danielsson LG. Elbow fractures in children. An epidemiological analysis of 589 cases. Acta Orthop Scand 1986;57:309-12. [CrossRef]

9. Jiatong $\mathrm{S}$, Wenjun L. Epidemiological characteristics and prevention and control measures of Coronavirus disease 2019 in children. J Trop Med 2020;20:153-6.

10. World Health Organization. WHO Characterizes COVID-19 as a Pandemic. 1.1 [EB/OL]. Geneva: World Health Organization; 2020. Available from: https://www.who.int/emergencies/diseases/novel-coronavirus-2019/events-as-they-happen. Accessed Mar 12, 2020.

11. de Bruin YB, Lequarre AS, McCourt J, Clevestig P, Pigazzani F, Jeddi $\mathrm{MZ}$, et al. Initial impacts of global risk mitigation measures taken during the combatting of the COVID-19 pandemic. Saf Sci 2020;128:104773.

12. Demirbilek Y, Pehlivantürk G, Özgüler Z, Alp Meșe E. COVID-19 out- break control, example of ministry of health of Turkey. Turk J Med Sci 2020;50:494-89. [CrossRef]

13. Tiderius CJ, Landin L, Düppe H. Decreasing incidence of fractures in children: An epidemiological analysis of 1673 fractures in Malmö, Sweden. Acta Orthop Scand 1999;70:622-6. [CrossRef]

14. Bram JT, Johnson MA, Magee LC, Mehta NN, Fazal FZ, Baldwin $\mathrm{KD}$, et al. Where have all the fractures gone? The epidemiology of pediatric fractures during the COVID-19 pandemic. J Pediatr Orthop 2020;40:373-9. [CrossRef]

15. Lyons RA, Delahunty AM, Kraus D, Heaven M, McCabe M, Allen H, et al. Children's fractures: A population based study. Inj Prev 1995;5:129-32.

16. Landin LA. Epidemiology of children's fractures. J Pediatr Orthop B 1997;6:79-83. [CrossRef]

17. Moustaki M, Loriou M, Petridou E. Cross country variation of fractures in the childhood population. Is the origin biological or "accidental"? Inj Prev 2001;7:77. [CrossRef]

18. Cheng JC, Ng BK, Ying SY, Lam PK. A 10-year study of the changes in the pattern and treatment of 6, 493 fractures. J Pediatr Orthop 1999;19:344-50. [CrossRef]

19. Clark EM. The epidemiology of fractures in otherwise healthy children. Curr Osteoporos Rep 2014;12:272-8. [CrossRef]

20. Randsborg PH, Gulbrandsen P, Benth JS, Sivertsen EA, Hammer OL, Fuglesang HF, et al. Fractures in children: Epidemiology and activity-specific fracture rates. J Bone Joint Surg Am 2013;95:e42. [CrossRef]

21. Joeris A, Lutz N, Wicki B, Slongo T, Audigé L. An epidemiological evaluation of pediatric long bone fractures-a retrospective cohort study of 2716 patients from two Swiss tertiary pediatric hospitals. BMC Pediatr 2014;14:314. [CrossRef]

22. Park MS, Chung CY, Choi IH, Kim TW, Sung KH, Lee SY, et al. Incidence patterns of pediatric and adolescent orthopaedic fractures according to age groups and seasons in South Korea: A population-based study. Clin Orthop Surg 2013;5:161-6. [CrossRef]

23. Jiang N, Cao ZH, Ma FY, Lin Z, Yu B. Management of pediatric forearm torus fractures: A systematic review and meta-analysis. Pediatr Emerg Care 2016;32:773-8. [CrossRef]

\section{ORIJJINAL ÇALIŞMA - ÖZ}

\section{COVID-19 pandemisi karantina döneminde pediatrik kırıkların özelliklerinin değerlendirilmesi \\ Dr. Alper Köksal,, Dr. Yalkin Çamurcu, ${ }^{2}$ Dr. Ferdi Dırvar,, ${ }^{1}$ Dr. Furkan Yapıcı, ${ }^{3}$ Dr. Hakan Akgün, ${ }^{1}$ Dr. Ozan Kaya ${ }^{1}$}

1Sağlık Bilimleri Üniversitesi, Baltalimanı Kemik Hastalıkları Eğitim ve Araştırma Hastanesi, Ortopedi ve Travmatoloji Anabilim Dalı, İstanbul ${ }^{2}$ İstanbul Atlas Üniversitesi Tıp Fakültesi, Ortopedi ve Travmatoloji Anabilim Dalı, İstanbul Türkiye

${ }^{3}$ Erzincan Binali Yildirim Üniversitesi Tıp Fakültesi, Ortopedi ve Travmatoloji Anabilim Dalı, Erzincan

AMAÇ: Bu çalışmanın amacı, uygulanan sosyal izolasyon önlemlerinin COVID- 19 pandemisine bağlı karantina döneminde pediatrik kırıkların özellikleri üzerindeki etkilerini araştırmaktır.

GEREÇ VE YÖNTEM: Merkezimize 3 Nisan 2019-3I Mayıs 2019 (karantina olmayan dönem) ve 3 Nisan 2020-3I Mayıs 2020 (karantina dönemi) olmak üzere iki dönem arasında başvuran hastalar çalışmaya dahil edildi. Grup I, karantina olmayan dönemde tedavi edilen 743 hastadan oluşurken, Grup 2, karantina döneminde tedavi edilen 615 hastadan oluşuyordu. Hastaların tıbbi kayıtları ve radyografileri hastanemizin bilgisayar veri tabanı üzerinden gözden geçirildi. Ek olarak, hastaların yaşı, cinsiyeti, kesin tanı, travmanın anatomik yeri, travma tipi (kırık, çıkık, tendon yaralanması, bağ yaralanması, kırıklı çıkık, açık kııık vb.), pediatrik kırık tipi (deplase kırık, torus kırı̆̆ı, epifız kırı̆ı̆, patolojik kırık, vb.) ve tedavi yöntemi (konservatif/ cerrahi) kaydedildi.

BULGULAR: Hastaların ortalama yaşı Grup 2'de anlamlı olarak daha düşüktü $(\mathrm{p}<0.00 \mathrm{I})$. Gruplar arasında travmaların anatomik lokalizasyonu açısından anlamlı farklılıklar vardı $(p<0.00 \mathrm{I})$. Travma tipleri, pediatrik travma ve tedavi gruplar arasında anlamlı olarak farklıydı (sırasıyla, $p<0.00$ ।, $p<0.00$ I ve $p<0.00$ I). Cerrahi tedavi sıklı̆ı Grup 2'de anlamlı olarak daha yüksekti $(p<0.00$ I).

TARTIŞMA: Sonuçlarımız, COVID- 19 pandemisi sırasında hasta demografisinde ve kırık özelliklerinde önemli farklılıklar göstermiştir. Anahtar sözcükler: Demografik; karantina; pandemi; pediatrik kırıklar.

Ulus Travma Acil Cerrahi Derg 2022;28(I):94-98 doi: 10.14744/tjtes.2020.6768 I 